\title{
High-dose insulin inhibits gap junction intercellular communication in vascular smooth muscle cells
}

\author{
OU BIAN, HAISHAN ZHANG, QIGANG GUAN, YINGXIAN SUN and DINGYIN ZENG
}

Department of Cardiology, The First Affiliated Hospital of China Medical University, Shenyang, Liaoning 110001, P.R. China

Received May 15, 2014; Accepted January 30, 2015

DOI: $10.3892 / \mathrm{mmr} .2015 .3437$

\begin{abstract}
Gap junction intercellular communication (GJIC) is important in mediating intercellular substance and signal transmission. Connexin (Cx)43 is a major component involved in GJIC in vascular tissue and its abnormal expression is closely associated with various vascular diseases. Insulin resistance is the central component of metabolic syndrome, and high doses of insulin can affect vascular function through multiple pathways, resulting in cardiovascular disease. However, the effects of insulin on GJIC function and connexin (CX)43 expression in vascular smooth muscle cells (VSMCs) remain unclear. Following treatment of VSMCs with different doses of insulin, a fluorescence recovery after photobleaching (FRAP) assay was performed to evaluate GJIC function in treated VSMCs. The results showed that high-dose insulin suppressed GJIC function. Western blot assays further demonstrated that high-dose insulin induced the phosphorylation of $\mathrm{Cx} 43$ at s368 and downregulated the expression of $\mathrm{Cx} 43 . \mathrm{H}_{2} \mathrm{O}_{2}$ release assays demonstrated that high-dose insulin treatment significantly elevated the cellular $\mathrm{H}_{2} \mathrm{O}_{2}$ level. In addition, compared with cells treated with high-dose insulin, pretreatment with catalase significantly restored the cellular GJIC function, decreased the phosphorylation level of $\mathrm{Cx} 43$ at s368, and enhanced $\mathrm{Cx} 43$ expression. In conclusion, these data indicate that high-dose insulin inhibits cellular GJIC function through the oxidative stress-activated signaling pathway. This phenomenon may also constitute a potential mechanism underlying the pathogenesis of insulin resistance and its complications.
\end{abstract}

Correspondence to: Dr Yingxian Sun or Dr Dingyin Zeng, Department of Cardiology, The First Affiliated Hospital of China Medical University, 155 North Nanjing, Shenyang, Liaoning 110001, P.R. China

E-mail: yingxiansun@hotmail.com

E-mail: dingyin_zeng@163.com

Key words: insulin, vascular smooth muscle cell, gap junction intercellular communication, connexin 43

\section{Introduction}

Gap junctions are membrane channel structures between neighboring cells that mediate gap junction intercellular communication (GJIC), which is an important pathway involved in intercellular substance and signal transmission. GJIC occurs throughout vascular tissues and is pivotal in the maintenance of normal vascular function (1-3) and the repair of vascular damage $(4,5)$. The basic structural unit of the gap junction is connexin. The major types of connexins expressed in vascular tissue include Cx43, Cx40, Cx37 and Cx45 (6), with Cx43 exhibiting the highest level of expression in this tissue $(7,8)$. The abnormal expression or dysfunction of $\mathrm{Cx} 43$ can affect the proliferation, migration and differentiation of vascular smooth muscle cells (VSMCs) (9-11). In addition, Cx43 participates in the pathophysiological processes of vasoconstriction (12-14), coronary artery spasm $(15,16)$ and atherosclerosis $(17-19)$.

Insulin is an important hormone involved in metabolic regulation and is required for the maintenance of normal blood vessel function (20). In insulin-resistant states, high levels of insulin in the blood are closely associated with various cardiovascular diseases (21-23). However, the involvement of insulin in the pathogenesis of cardiovascular diseases through its effects on connexin and GJIC remains unclear. In this study, by treating VSMCs with different doses of insulin, the effects of insulin on GJIC, Cx43 phosphorylation, and Cx43 expression were explored under physiological and pathological conditions (presence of 1 or $100 \mathrm{nmol} / \mathrm{l}$ insulin, respectively). Furthermore, the possible mechanisms underlying these effects of insulin were investigated. The aim of this study was to clarify the molecular mechanisms that contribute to vascular dysfunction in conditions associated with insulin resistance.

\section{Materials and methods}

Cell culture. All animal treatment procedures were performed in accordance with the provisions of the Institutional Animal Ethics Committee of China Medical University. The present study was approved by the ethics committee of China Medical University (Shenyang, China). Eight-week-old healthy Sprague-Dawley rats were obtained from the Experimental Animal Center of China Medical University (Shenyang, China). The rats were housed under specific pathogen-free conditions $\left(23 \pm 2^{\circ} \mathrm{C}, 60 \pm 5 \%\right.$ humidity, $12: 12 \mathrm{~h}$ light:dark cycle) and allowed free access to food and water. The rats were sacrificed by ether 
inhalation after 1 week and their thoracic aortas were harvested under sterile conditions. As described previously (24), primary VSMCs were dissociated. Briefly, the thoracic aortas were washed in pre-cooled phosphate-buffered saline (PBS), and the adventitia and intima were removed. Subsequently, the reserved media tunica was transferred to a culture flask, cut into $\sim 1 \mathrm{~mm}^{3}$ sections, stuck to the bottom and the bubbles were pressed out by tweezers. The flask was gently flipped upside down and 5-6 ml Dulbecco's modified Eagle's medium (DMEM, Gibco, Grand Island, NY) containing 10\% fetal bovine serum (FBS; Hyclone, Logan, UT, USA) was added. The culture flask was cultured in an incubator containing $5 \% \mathrm{CO}_{2}$ and $95 \%$ air, at $37^{\circ} \mathrm{C}$. After $4 \mathrm{~h}$, the flask was returned to an upright position and the tissue was completely immersed in the culture medium for 5-7 days. The VMSCs that had grown out from the edges of the tissue blocks were digested using $0.25 \%$ trypsin (Beyotime Institute of Biotechnology, Haimen, China), seeded in a new flask and cultured in DMEM containing 10\% FBS, 2 mmol glutamate (Beijing Solarbio Science \& Technology Co., Ltd., Beijing, China), $100 \mathrm{U} / \mathrm{ml}$ penicillin (Beijing Solarbio Science \& Technology Co., Ltd.) and $100 \mu \mathrm{g} / \mathrm{ml}$ streptomycin (Beijing Solarbio Science \& Technology Co., Ltd.) at $37^{\circ} \mathrm{C}$ in a cell culture incubator with $5 \% \mathrm{CO}_{2}$. The purity of cultured VSMCs was determined using immunocytochemical stanining with a monoclonal antibody specific for $\alpha$-actin.

Immunocytochemistry. Briefly, VMSCs were grown to subconfluence on coverslips, fixed in 4\% paraformaldehyde (Sinopharm Chemical Reagent, Shanghai, China) and permeabilized with $0.5 \%$ Triton X-100 (Beijing Solarbio Science \& Technology Co., Ltd.). Following treatment with $3 \%$ hydrogen peroxide (Sinopharm Chemical Reagent) and 5\% bovine serum albumin (Beijing Solarbio Science \& Technology Co., Ltd.), the coverslips were incubated overnight at $4^{\circ} \mathrm{C}$ with a mouse monoclonal antibody targeting $\alpha$-actin (1:300 dilution; cat. no. sc-58669; Santa Cruz Biotechnology, Inc., Dallas, TX, USA). The coverslips were then incubated at $37^{\circ} \mathrm{C}$ for $40 \mathrm{~min}$ with a biotinylated goat anti-mouse immunoglobulin $\mathrm{G}$ antibody (cat. no. A0286; Beyotime Institute of Biotechnology). Immunostaining was detected using streptavidin-horseradish peroxidase conjugate (Beyotime Institute of Biotechnology) and visualized with 3, 3'-diaminobenzidine (Beyotime Institute of Biotechnology). Finally, the sections were counterstained with hematoxylin (Beijing Solarbio Science \& Technology Co., Ltd.) and observed under a light microscope (DP73; Olympus, Tokyo, Japan).

Experimental grouping and determination of glucose uptake. VSMCs were inoculated into 24-well plates and cultured in a cell culture incubator. After $24 \mathrm{~h}$ in culture, 1 or $100 \mathrm{nmol} / \mathrm{l}$ insulin was added to the culture medium, followed by incubation for another $24 \mathrm{~h}$. The glucose uptake of each group of cells was measured as described by Pyla et al (25). Briefly, the cells were washed with Krebs-Ringer-HEPES buffer containing $15 \mathrm{mmol} / 1 \mathrm{HEPES}, 105 \mathrm{mmol} / \mathrm{l} \mathrm{NaCl}, 5 \mathrm{mmol} / \mathrm{l}$ $\mathrm{KCl}, 1.4 \mathrm{mmol} / 1 \mathrm{CaCl}_{2}, 1 \mathrm{mmol} / 1 \mathrm{KH}_{2} \mathrm{PO}_{4}, 1.4 \mathrm{mmol} / 1 \mathrm{MgSO}_{4}$ and $10 \mathrm{mmol} / 1 \mathrm{NaHCO}_{3}, \mathrm{pH}$ 7.4; followed by incubation in a $0.2 \mathrm{mmol} / \mathrm{l}$ 2-deoxy-D-glucose (2-DG) solution containing

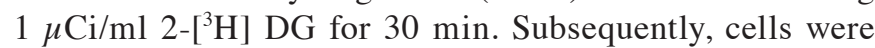
washed three times with pre-cooled phosphate-buffered saline and lysed with $0.4 \mathrm{~mol} / 1 \mathrm{NaOH}$. After neutralization with $\mathrm{HCl}$, aliquots of cell lysate were used to determine glucose uptake with a liquid scintillation spectrometer (PerkinElmer Wallac, Inc., Gaithersburg, MD, USA).

Fluorescence recovery after photobleaching (FRAP) assay. FRAP experiments were conducted as previously described (26). After VSMCs grew to $80 \%$ confluence, different concentrations of insulin $(0,1$ or $100 \mathrm{nmol} / \mathrm{l})$ were added to the culture medium. After $24 \mathrm{~h}$, the culture medium was discarded, and the cells were treated with 6-carboxyfluorescein diacetate (6-CFDA, Invitrogen Life Technologies, Carlsbad, CA, USA) at a final concentration of $10 \mu \mathrm{mol} / 1$ for $20 \mathrm{~min}$. 6-CFDA can easily pass through cell membranes and decompose into 6-CF, which cannot pass through cell membranes, but can spread through gap junctions (27). The excitation wavelength of 6-CF is $490 \mathrm{~nm}$, and cells labeled with it can be observed as green under a fluorescent microscope. After washing twice with D-Hank's solution, the cells were observed under a laser-scanning confocal microscope (FV1000S-SIM/IX81; Olympus).

Three types of cells were selected for the FRAP assay. The first type included cells that tightly connected with neighboring cells and demonstrated GJIC. The fluorescence recovery after photobleaching of these cells reflected the level of GJIC. The second type included isolated cells that did not demonstrate GJIC with neighboring cells and thus were used as a self-control in this experiment. The third type included cells that were tightly connected with neighboring cells and showed spontaneous photobleaching. This type of cells did not require photobleaching and thus were used for background correction. Photobleaching was conducted with a laser power of $500 \mathrm{~mW}$, duration of the photobleaching pulse of $200 \mathrm{msec}$, a bleaching rate of $30-60 \%$, a bleaching intensity of $100 \%$, and a scanning intensity of $20 \%$. After computer-assisted precise positioning, intracellular fluorescence in selected cells was bleached with a laser beam. The bleached cell was then monitored, and images were acquired (FV1000 confocal operations software; Olympus) continuously every $10 \mathrm{sec}$ for $5 \mathrm{~min}$ for the detection of fluorescence recovery. The maximum fluorescence recovery proportion and the fluorescence recovery rate were used as indicators for the evaluation of GJIC in each group. The fluorescence recovery rate after photobleaching was calculated with the following formula: $\left[\left(\mathrm{I}_{\mathrm{t}}-\mathrm{I}_{0}\right) /\left(\mathrm{I}-\mathrm{I}_{0}\right) \times 100 \%\right] / t$, where $\mathrm{I}_{\mathrm{t}}$ is the relative fluorescence intensity at the time point $t$ in the bleached cell, $\mathrm{I}_{0}$ is the relative fluorescence intensity immediately after bleaching, $\mathrm{I}$ is the relative fluorescence intensity prior to bleaching and $t$ is the recovery time. A third-party software program, Olympus Fluoview V2.1C (Olympus), was used to automatically analyze the data.

Western blot analysis. Cells were lysed using radioimmunoprecipitation assay lysis buffer (Beyotime Institute of Biotechnology), and protein concentrations were quantified by the bicinchoninic acid method (Beyotime Institute of Biotechnology). Equal quantities of total proteins $(40 \mu \mathrm{g})$ were separated by sodium dodecyl sulfate-polyacrylamide gel electrophoresis and electrotransferred onto a polyvinylidene difluoride membrane (Millipore, Bedford, MA, USA). The membranes were blocked with 5\% skimmed milk for $1 \mathrm{~h}$ and incubated overnight at $4^{\circ} \mathrm{C}$ with the following primary anti- 

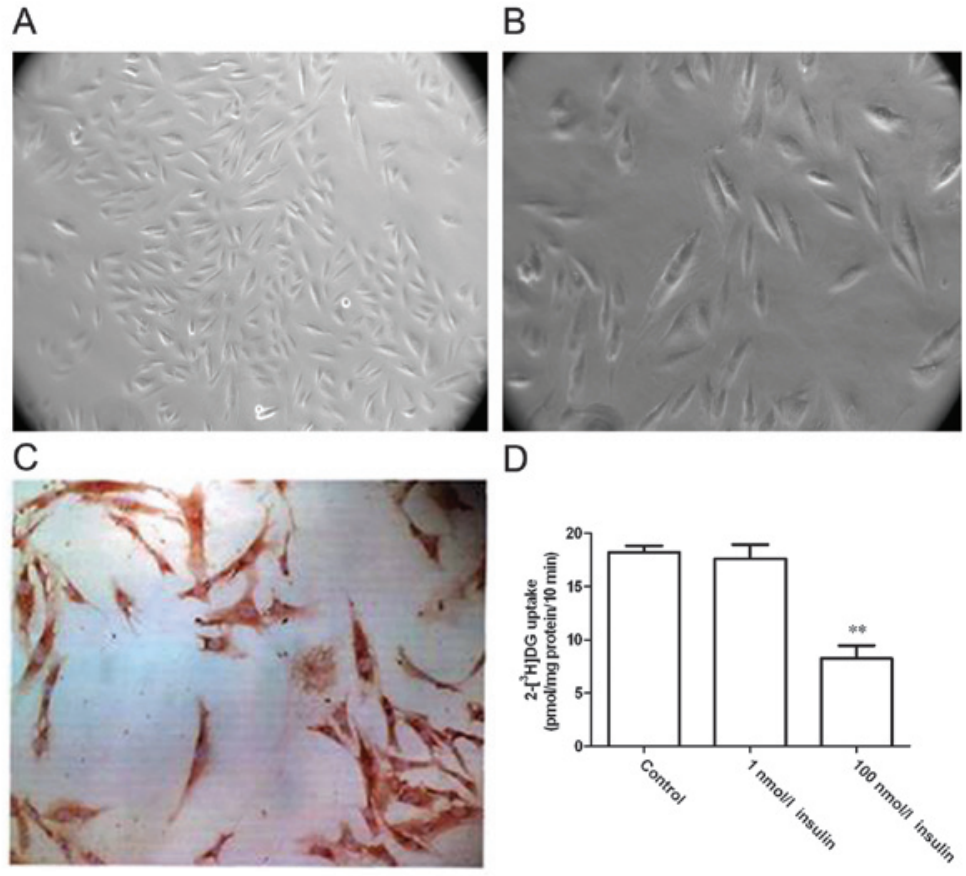

D

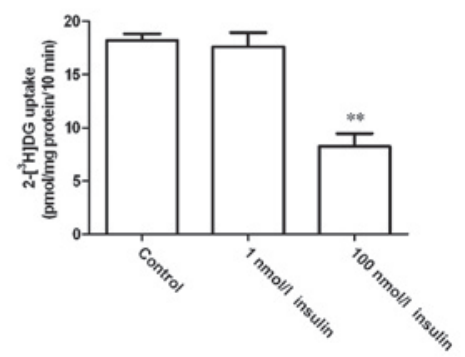

Figure 1. Observations of VSMCs and cell glucose uptake. (A) Primary VSMCs viewed under an inverted microscope (magnification, x100). (B) Primary VSMCs viewed under an inverted microscope (magnification, x200). (C) Immunostaining for $\alpha$-actin in VSMCs (magnification, $\mathrm{x} 100$ ). (D) Cellular glucose uptake rates, $\mathrm{n}=5$. $^{* *} \mathrm{P}<0.01$, compared with the control group. VSMCs, vascular smooth muscle cells.

bodies: Rabbit polyclonal anti-Cx43 (cat. no. ab11370) or rabbit polyclonal anti-p-Cx43 (cat. no. ab30559; Abcam, Cambridge, MA, USA) at dilutions of 1:1,000 and 1:800, respectively. After washing with PBS, the membranes were incubated with horseradish peroxidase-conjugated secondary antibodies (cat. no. sc-2054; Santa Cruz Biotechnology, Inc.) at 1:5,000 dilutions for $1 \mathrm{~h}$ at $37^{\circ} \mathrm{C}$. Subsequently, the blotted protein bands were exposed to and visualized with enhanced chemiluminescence reagents (Millipore). Developed films were digitized by scanning, and the optical densities were analyzed with Image $\mathrm{J}$ version $1.43 \mathrm{~b}$ software (National Institutes of Health, Bethesda, MD, USA). $\beta$-actin was used as an internal control for the analysis of protein expression.

Detection of $\mathrm{H}_{2} \mathrm{O}_{2}$ activity. Intracellular hydrogen peroxide levels were measured using an Amplex Red Hydrogen Peroxide Assay kit (Invitrogen Life Technologies), strictly following the instructions provided in the user manual.

Statistical analysis. All data are presented as the mean \pm standard deviation. Comparisons between groups were conducted using one-way analysis of variance, and $\mathrm{P}<0.05$ was considered to indicate a statistically significant difference. GraphPad Prism 5.0 software (GraphPad Software Inc., La Jolla, CA, USA) was used for graph processing.

\section{Results}

Identification of VSMCs and the effect on glucose uptake following different doses of insulin. A tissue adherent cultivation approach was adopted to separate VSMCs. After 5-7 days, smooth muscle cells grew out from the edges of the tissue blocks. The cells were fusiform- or spindle-shaped, rela- tively small in size with ovoid-shaped nuclei, and the cytoplasm displayed strong light refraction (Fig. 1A and B). After culturing for 3-4 weeks, the cells formed monolayers and displayed a typical 'peak-to-valley' growth. Immunocytochemical staining for $\alpha$-actin, a specific marker of VSMCs, demonstrated that the majority of cells were $\alpha$-actin-positive with a large quantity of brown-yellowish myofilaments in an arrangement parallel to the longitudinal axis of the cell (Fig. 1C). These observations indicated the successful acquisition of VSMCs. Then, the cells were treated with different concentrations of insulin and glucose uptake was assessed after $24 \mathrm{~h}$ (Fig. 1D). Compared with the control group, the glucose uptake rate did not show significant changes in cells treated with $1 \mathrm{nmol} / 1$ insulin $(\mathrm{P}>0.05)$, although this rate was significantly decreased in cells treated with $100 \mathrm{nmol} / 1$ insulin $(\mathrm{P}<0.01)$. These results indicate that high-dose insulin reduced the sensitivity of VSMCs to insulin and led to a state of insulin resistance.

High-dose insulin suppresses GJIC and induces the phosphorylation of Cx43 at s368. FRAP assays were performed to evaluate the effect of insulin on GJIC in VSMCs (Fig. 2A and $\mathrm{B})$. The results showed that $1 \mathrm{nmol} / 1$ insulin did not induce significant changes in the maximum fluorescence recovery proportion or the fluorescence recovery rate of treated cells, while treatment with $100 \mathrm{nmol} / \mathrm{l}$ insulin for $24 \mathrm{~h}$ significantly decreased these readouts $(\mathrm{P}<0.01)$. These results suggested that high-dose insulin could suppress the GJIC function of VSMCs. Furthermore, western blotting showed that cells treated with $100 \mathrm{nmol} / 1$ insulin demonstrated a significantly higher level of phosphorylated Cx43 at s368 and a significantly decreased level of $\mathrm{Cx} 43$ (both $\mathrm{P}<0.05$ ) (Fig. 2C and D). This result indicated that high-dose insulin promotes the phosphorylation of Cx43 at s368 and downregulates the level of Cx43. 
A

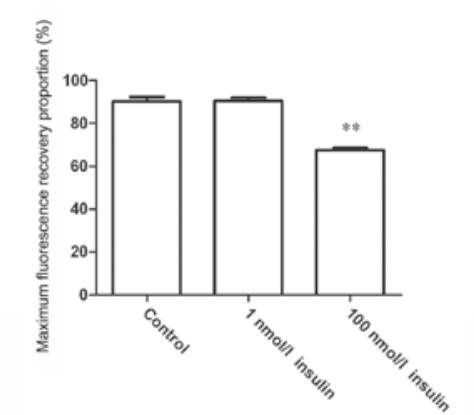

C

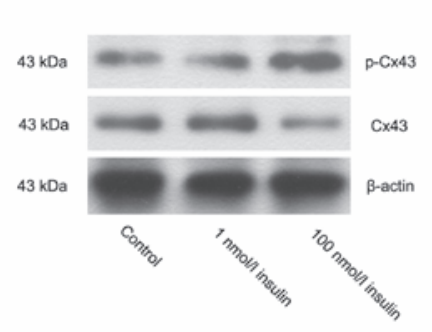

B

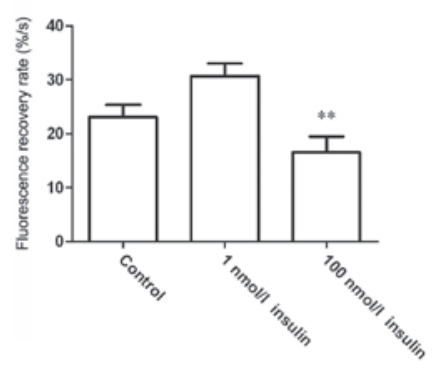

D

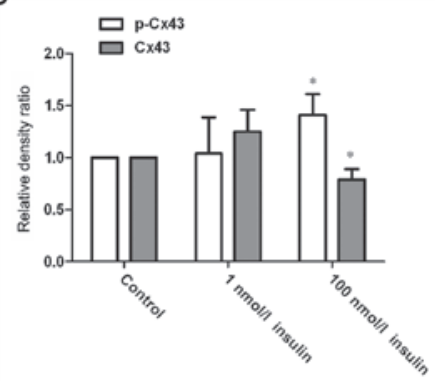

Figure 2. Fluorescence recovery and Cx43 expression in VSMCs treated with different concentrations of insulin. (A) Maximum fluorescence recovery proportion, $n=6$. (B) The fluorescence recovery rate, $n=6$. (C) Western blotting for $\mathrm{Cx} 43$ phosphorylation at $\mathrm{s} 368$ and $\mathrm{Cx} 43$ expression; representative results are presented in the figure. (D) The phosphorylation of $\mathrm{Cx} 43$ at s368 and the relative expression level of $\mathrm{Cx} 43, \mathrm{n}=3 .{ }^{*} \mathrm{P}<0.05$ and ${ }^{* * *} \mathrm{P}<0.01$, compared with the control group. VSMCs, vascular smooth muscle cells; Cx43, connexin 43.

High-dose insulin induces $\mathrm{H}_{2} \mathrm{O}_{2}$ release from VSMCs. $\mathrm{H}_{2} \mathrm{O}_{2}$ activity was measured to explore the mechanisms underlying the effect of insulin on GJIC (Fig. 3). Treatment with $1 \mathrm{nmol} / \mathrm{l}$ insulin did not exert a significant impact on cellular $\mathrm{H}_{2} \mathrm{O}_{2}$ activity, while treatment with $100 \mathrm{nmol} / \mathrm{l}$ insulin for $24 \mathrm{~h}$ significantly enhanced the cellular $\mathrm{H}_{2} \mathrm{O}_{2}$ level $(\mathrm{P}<0.01)$, indicating that the effect of high-dose insulin on GJIC may be correlated with the release of $\mathrm{H}_{2} \mathrm{O}_{2}$.

High-dose insulin promotes the phosphorylation of $\mathrm{Cx} 43$ and inhibits GJIC via the release of $\mathrm{H}_{2} \mathrm{O}_{2}$. VSMCs were pre-treated with $2,000 \mathrm{U} / \mathrm{ml}$ catalase $30 \mathrm{~min}$ prior to the insulin treatment, and then the GJIC level was measured (Fig. 4A and B). Compared with cells treated with only high-dose insulin, the maximum fluorescence recovery proportion and the fluorescence recovery rate were significantly increased in cells pretreated with catalase $(\mathrm{P}<0.01)$. Western blotting further revealed that compared with cells treated with only high-dose insulin, catalase-pretreated cells showed a significantly decreased phosphorylation level of $\mathrm{Cx} 43$ at s368 and an elevated $\mathrm{Cx} 43$ expression level (Fig. $4 \mathrm{C}$ and $\mathrm{D} ; \mathrm{P}<0.05$ ).

\section{Discussion}

It has been shown that insulin affects the proliferation, migration, phenotypic transformation and cellular contraction of VSMCs, and is involved in the occurrence and development of cardiovascular disease (28-30). GJIC is an important pathway contributing to intercellular substance and signal transmission and thus is crucial in the maintenance of normal vascular function. However, the effect of insulin on intracellular GJIC remains unclear. In this study, using different concentrations of insulin to treat in vitro-cultured VSMCs, it was observed that high-dose insulin suppressed cellular GJIC function, promoted the phosphorylation of $\mathrm{Cx} 43$ at s368 and downregulated the expression of $\mathrm{Cx} 43$. In addition, high-dose insulin treatment enhanced $\mathrm{H}_{2} \mathrm{O}_{2}$ release. Furthermore, catalase pretreatment significantly restored GJIC function, which was accompanied by decreased phosphorylation of $\mathrm{Cx} 43$ at s 368 and increased Cx43 expression. These results indicate that high-dose insulin can regulate GJIC in VSMCs through the mediation of oxidative stress.

Insulin can promote glucose uptake and utilization in tissues and cells, and thus serves as an essential hormone in glucose metabolism. In the clinic, insulin resistance refers to the physiological condition in which reduced glucose uptake and utilization efficiencies lead to a compensatory increase in insulin secretion to maintain glucose hemostasis in the body (31). Hyperinsulinemia is often used as one of the diagnostic criteria for insulin resistance. Due to the limitations of human research, the majority of studies have treated cells with high-dose insulin for studies of the pathogenesis of insulin resistance $(32,33)$. In this study, insulin doses of 1 and $100 \mathrm{nmol} / \mathrm{l}$ in VSMCs were used to evaluate its effects on vascular states under physiological and pathological conditions. The results demonstrated that insulin at a physiological concentration did not significantly affect glucose uptake, while high-dose insulin significantly reduced the glucose uptake rate. The findings are consistent with the conclusions drawn in previous studies (34).

Vascular tissue displays abundant GJIC, which is extensively involved in various physiological functions of blood vessels and is closely associated with the occurrence and development of various diseases (35). By treating VSMCs with different concentrations of insulin, it was observed that high-dose insulin could 


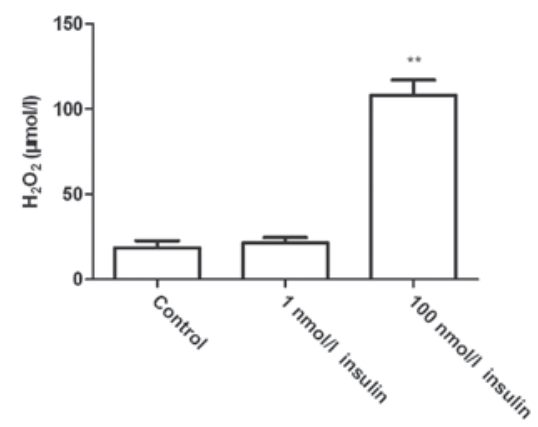

Figure 3. Cellular $\mathrm{H}_{2} \mathrm{O}_{2}$ content in VSMCs treated with difference concentrations of insulin, $n=3$. ${ }^{* *} \mathrm{P}<0.01$, compared with the control group. VSMCs, vascular smooth muscle cells.

A

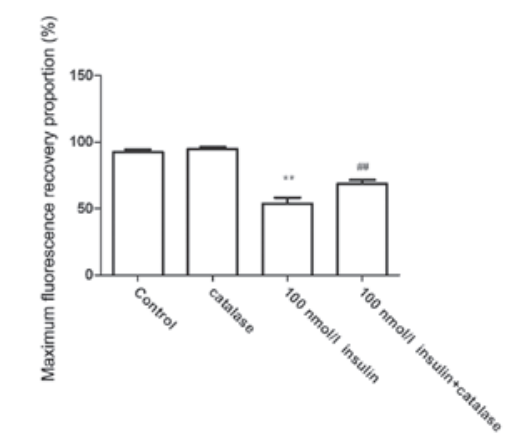

C

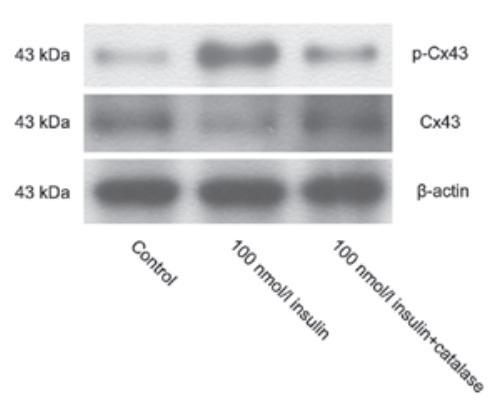

B
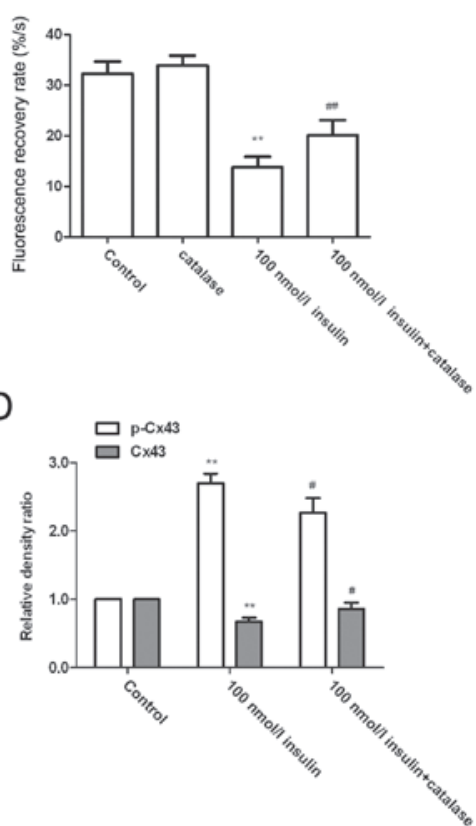

Figure 4. Fluorescence recovery and Cx43 expression in VSMCs following treatment with catalase. (A) The maximum fluorescence recovery proportion, $\mathrm{n}=6$. (B) The fluorescence recovery rate, $\mathrm{n}=6$. (C) Western blotting for $\mathrm{Cx} 43$ phosphorylation at $\mathrm{s} 368$ and $\mathrm{Cx} 43$ expression; representative results from three repeated experiments are presented in the figure. (D) The phosphorylation of Cx43 at $\mathrm{s} 368$ and the relative expression level of $\mathrm{Cx} 43, \mathrm{n}=3$. ${ }^{* *} \mathrm{P}<0.01, \mathrm{compared}$ with the control group. ${ }^{\#} \mathrm{P}<0.05$ and ${ }^{\# \#} \mathrm{P}<0.01$ compared with the $100 \mathrm{nmol} / 1$ insulin treatment group. VSMCs, vascular smooth muscle cells.

suppress GJIC in VSMCs. Therefore, abnormal GJIC function may contribute to the pathogenesis of insulin resistance. Among all connexins present in vascular tissue, Cx43 shows the highest protein expression level, and multiple studies have shown that abnormal phosphorylation of Cx43 at s368 can downregulate Cx43 expression and inhibit GJIC function $(36,37)$. In this study, it was observed that high-dose insulin induced abnormal phosphorylation of $\mathrm{Cx} 43$ at s368 and downregulated $\mathrm{Cx} 43$ expression, indicating that the high-dose insulin-induced reduction of GJIC function may be associated with the abnormal phosphorylation of $\mathrm{Cx} 43$ at s368.

Currently, it is hypothesized that high-dose insulin induces insulin resistance, type 2 diabetes (38), atherosclerosis (39), hypertension (40) and obesity (41) primarily through the induction of oxidative stress responses $(42,43) . \mathrm{H}_{2} \mathrm{O}_{2}$ is a stable component of reactive oxygen species in VSMCs and is also a second messenger for various stimulators in smooth muscle cells (44). The current study demonstrated that high-dose insulin could induce a release of $\mathrm{H}_{2} \mathrm{O}_{2}$, which is consistent with the conclusions drawn from previous studies (45). In addition, the inhibition of GJIC function by $\mathrm{H}_{2} \mathrm{O}_{2}$ through the induction of $\mathrm{Cx} 43$ phosphorylation has been verified in various types of cells $(46,47)$. In this study, catalase pretreatment reversed the high-dose insulin-induced inhibition of GJIC, decreased the phosphorylation level of $\mathrm{Cx} 43$ at s368, and upregulated $\mathrm{Cx} 43$ expression. These findings further confirmed that high-dose insulin could promote $\mathrm{Cx} 43$ phosphorylation through the induction of $\mathrm{H}_{2} \mathrm{O}_{2}$ release, thus suppressing GJIC function.

In conclusion, through the activation of oxidative stress responses, high-dose insulin treatment induced $\mathrm{Cx} 43$ phosphorylation and downregulated $\mathrm{Cx} 43$ expression, thus suppressing GJIC function. This process may contribute to the pathogenesis of insulin resistance, although the detailed mechanisms require further investigation in in-depth studies. 


\section{Acknowledgements}

This study was supported by a grant from the National Basic Research Program of China (973 Program, no. 2012CB518606).

\section{References}

1. Chadjichristos CE, Morel S, Derouette JP, et al: Targeting connexin 43 prevents platelet-derived growth factor-BB-induced phenotypic change in porcine coronary artery smooth muscle cells. Circ Res 102: 653-660, 2008.

2. Inoguchi T, Yu HY, Imamura M, et al: Altered gap junction activity in cardiovascular tissues of diabetes. Med Electron Microsc 34: 86-91, 2001.

3. Figueroa XF, Isakson BE and Duling BR: Connexins: gaps in our knowledge of vascular function. Physiology (Bethesda) 19 277-284, 2004

4. Coutinho P, Qiu C, Frank S, Tamber K and Becker D: Dynamic changes in connexin expression correlate with key events in the wound healing process. Cell Biol Int 27: 525-541, 2003.

5. Liao Y, Regan CP, Manabe I, et al: Smooth muscle-targeted knockout of connexin43 enhances neointimal formation in response to vascular injury. Arterioscler Thromb Vasc Biol 27: $1037-1042,2007$.

6. Johnstone S, Isakson B and Locke D: Biological and biophysical properties of vascular connexin channels. Int Rev Cell Mol Biol 278: 69-118, 2009.

7. Evans WH and Martin PE: Gap junctions: structure and function (Review). Mol Membr Biol 19: 121-136, 2002.

8. Haefliger JA, Nicod P and Meda P: Contribution of connexins to the function of the vascular wall. Cardiovasc Res 62: 345-356, 2004

9. Joshi CN, Martin DN, Shaver P, Madamanchi C, Muller-Borer BJ and Tulis DA: Control of vascular smooth muscle cell growth by connexin 43. Front Physiol 3: 220, 2012.

10. Johnstone SR, Kroncke BM, Straub AC, et al: MAPK phosphorylation of connexin 43 promotes binding of cyclin $\mathrm{E}$ and smooth muscle cell proliferation. Circ Res 111: 201-211, 2012.

11. Jia G, Cheng G, Gangahar DM and Agrawal DK: Involvement of connexin 43 in angiotensin II-induced migration and proliferation of saphenous vein smooth muscle cells via the MAPK-AP-1 signaling pathway. J Mol Cell Cardiol 44: 882-890, 2008.

12. Earley S, Resta TC and Walker BR: Disruption of smooth muscle gap junctions attenuates myogenic vasoconstriction of mesenteric resistance arteries. Am J Physiol Heart Circ Physiol 287: H2677-H2686, 2004.

13. Rocha ML, Kihara AH, Davel AP, Britto LR, Rossoni LV and Bendhack LM: Blood pressure variability increases connexin expression in the vascular smooth muscle of rats. Cardiovasc Res 80: 123-130, 2008.

14. Slovut DP, Mehta SH, Dorrance AM, Brosius FC, Watts SW and Webb RC: Increased vascular sensitivity and connexin 43 expression after sympathetic denervation. Cardiovasc Res 62 : 388-396, 2004

15. Hong T, Wang $\mathrm{H}$ and Wang Y: Effects of gap junctional blockers on cerebral vasospasm after subarachnoid hemorrhage in rabbits. Neurol Res 31: 238-244, 2009.

16. Wang $\mathrm{H}$, Hong $\mathrm{T}$, Wang $\mathrm{H}$ and Wang $\mathrm{Y}$ : Altered expression of connexin 43 and its possible role in endothelin-1-induced contraction in rabbit basilar artery. Neurol Res 31: 67-73, 2009.

17. Wei JM, Wang X, Gong H, Shi YJ and Zou Y: Ginkgo suppresses atherosclerosis through downregulating the expression of connexin 43 in rabbits. Arch Med Sci 9: 340-346, 2013.

18. Kwak BR, Mulhaupt F, Veillard N, Gros DB and Mach F: Altered pattern of vascular connexin expression in atherosclerotic plaques. Arterioscler Thromb Vasc Biol 22: 225-230, 2002.

19. Kwak BR, Veillard N, Pelli G, et al: Reduced connexin 43 expression inhibits atherosclerotic lesion formation in low-density lipoprotein receptor-deficient mice. Circulation 107: 1033-1039, 2003.

20. Breen DM and Giacca A: Effects of insulin on the vasculature. Curr Vasc Pharmacol 9: 321-332, 2011.

21. Anfossi G, Russo I, Doronzo G and Trovati M: Contribution of insulin resistance to vascular dysfunction. Arch Physiol Biochem 115: 199-217, 2009

22. Muniyappa R, Montagnani M, Koh KK and Quon MJ: Cardiovascular actions of insulin. Endocr Rev 28: 463-491, 2007.

23. Muniyappa R and Quon MJ: Insulin action and insulin resistance in vascular endothelium. Curr Opin Clin Nutr Metab Care 10: 523-530, 2007.
24. Lo HM, Hung CF, Tseng YL, Chen BH, Jian JS and Wu WB Lycopene binds PDGF-BB and inhibits PDGF-BB-induced intracellular signaling transduction pathway in rat smooth muscle cells. Biochem Pharmacol 74: 54-63, 2007.

25. Pyla R, Poulose N, Jun JY and Segar L: Expression of conventional and novel glucose transporters, GLUT1, $-9,-10$ and -12 , in vascular smooth muscle cells. Am J Physiol Cell Physiol 304: C574-C589, 2013.

26. Shen J, Wang LH, Zheng LR, Zhu JH and Hu SJ: Lovastatin inhibits gap junctional communication in cultured aortic smooth muscle cells. J Cardiovasc Pharmacol Ther 15: 296-302, 2010.

27. Tao R, Hu MF, Lou JT and Lei YL: Effects of H pylori infection on gap-junctional intercellular communication and proliferation of gastric epithelial cells in vitro. World J Gastroenterol 13: 5497-5500, 2007.

28. Zhang Y, Wang Y, Wang X, et al: Insulin promotes vascular smooth muscle cell proliferation via microRNA-208-mediated downregulation of p21. J Hypertens 29: 1560-1568, 2011.

29. Wang CC, Gurevich I and Draznin B: Insulin affects vascular smooth muscle cell phenotype and migration via distinct signaling pathways. Diabetes 52: 2562-2569, 2003.

30. Salt IP: Examining the role of insulin in the regulation of cardiovascular health. Future Cardiol 9: 39-52, 2013.

31. Reaven GM: The insulin resistance syndrome: Definition and dietary approaches to treatment. Annu Rev Nutr 25: 391-406, 2005.

32. Zhang WY, Lee JJ, Kim Y, et al: Effect of eriodictyol on glucose uptake and insulin resistance in vitro. J Agric Food Chem 60: 7652-7658, 2012.

33. Niu P, Zhang Y, Shi D, Chen Y and Deng J: Cardamonin ameliorates insulin resistance induced by high insulin and high glucose through the mTOR and signal pathway. Planta Med 79: 452-458, 2013 .

34. Liu G, Hitomi H, Hosomi N, et al: Mechanical stretch augments insulin-induced vascular smooth muscle cell proliferation by insulin-like growth factor-1 receptor. Exp Cell Res 317: 2420-2428, 2011

35. Figueroa XF and Duling BR: Gap junctions in the control of vascular function. Antioxid Redox Signal 11: 251-266, 2009.

36. Lim MC, Maubach G and Zhuo L: TGF-beta1 down-regulates connexin 43 expression and gap junction intercellular communication in rat hepatic stellate cells. Eur J Cell Biol 88: 719-730, 2009.

37. Richards TS, Dunn CA, Carter WG, Usui ML, Olerud JE and Lampe PD: Protein kinase C spatially and temporally regulates gap junctional communication during human wound repair via phosphorylation of connexin43 on serine368. J Cell Biol 167: 555-562, 2004.

38. Weyer C, Funahashi T, Tanaka S, et al: Hypoadiponectinemia in obesity and type 2 diabetes: Close association with insulin resistance and hyperinsulinemia. J Clin Endocrinol Metab 86: 1930-1935, 2001

39. Fujiwara T, Saitoh S, Takagi S, et al: Development and progression of atherosclerotic disease in relation to insulin resistance and hyperinsulinemia. Hypertens Res 28: 665-670, 2005.

40. DeFronzo RA and Ferrannini E: Insulin resistance. A multifaceted syndrome responsible for NIDDM, obesity, hypertension, dyslipidemia, and atherosclerotic cardiovascular disease. Diabetes Care 14: 173-194, 1991.

41. Lewis GF, Uffelman KD, Szeto LW and Steiner G: Effects of acute hyperinsulinemia on VLDL triglyceride and VLDL apoB production in normal weight and obese individuals. Diabetes 42 : 833-842, 1993.

42. Henriksen EJ, Diamond-Stanic MK and Marchionne EM: Oxidative stress and the etiology of insulin resistance and type 2 diabetes. Free Radic Biol Med 51: 993-999, 2011.

43. Tiganis T: Reactive oxygen species and insulin resistance: the good, the bad and the ugly. Trends Pharmacol Sci 32: 82-89, 2011.

44. Cowan DB, Jones M, Garcia LM, et al: Hypoxia and stretch regulate intercellular communication in vascular smooth muscle cells through reactive oxygen species formation. Arterioscler Thromb Vasc Biol 23: 1754-1760, 2003

45. Yang M, Yang Y, Zhang S and Kahn AM: Insulin-stimulated hydrogen peroxide increases guanylate cyclase activity in vascular smooth muscle. Hypertension 42: 569-573, 2003.

46. Hwang JW, Park JS, Jo EH, et al: Chinese cabbage extracts and sulforaphane can protect $\mathrm{H}_{2} \mathrm{O}_{2}$-induced inhibition of gap junctional intercellular communication through the inactivation of ERK1/2 and p38 MAP kinases. J Agric Food Chem 53: 8205-8210, 2005.

47. Lee KW, Hur HJ, Lee HJ and Lee CY: Antiproliferative effects of dietary phenolic substances and hydrogen peroxide. J Agric Food Chem 53: 1990-1995, 2005 